\title{
Tartu as the Eastern Outpost of European Medicine in the First Half of the $17^{\text {th }}$ Century
}

\author{
Kaarina Rein \\ Language Centre \\ University of Tartu \\ Jakobi 2-232, \\ Tartu 51014, Estonia \\ E-mail: Kaarina.Rein@ut.ee
}

\begin{abstract}
The history of medicine in Tartu begins with medieval monastic medicine. There is data about an infirmary and an almshouse at the Holy Spirit Church, which were probably founded in the middle of the $13^{\text {th }}$ century. The first pharmacy in Tartu was founded between 1422 and 1430 by a learned physician who arrived from Tallinn. Up to the beginning of the $17^{\text {th }}$ century, the owners of the pharmacy were the only representatives of academic medicine in Tartu. Academic medical education in Tartu had its beginnings with the academic gymnasium founded in 1630 and the university founded in 1632. One of the three higher faculties at the University of Tartu at that time was the Faculty of Medicine. It was planned to have two professorships, although in reality only one professor of medicine was employed. The model of the University of Paris demanded that all "proper" universities must have a medical faculty. There were very few students studying at the Faculty of Medicine in Tartu in the $17^{\text {th }}$ century. Only two names-David Cunitius and Olaus Oestenius-could be mentioned from among those who studied medicine at Academia Gustaviana and were later active as physicians. There were also students who studied in some other faculty in Tartu and later continued their studies in the field of medicine elsewhere in Europe. However, the Swedish University of Tartu can be considered an important centre of early modern medical thought in the Eastern Europe.
\end{abstract}

The article tries to give some idea about the medical situation in Tartu before the founding of the University of Tartu and during its early period of existence. The task is to investigate whether the academic medicine of the first half of the $17^{\text {th }}$ century has introduced any changes into the history of medicine of Tartu. 
Keywords: academic medicine in the $17^{\text {th }}$ century, disputations and orations in Early Modern universities, history of medicine, history of science, history of the University of Tartu

\section{Medicine in Tartu before the founding of the university}

The first representatives of European medicine in the Baltic provinces were probably clergymen and monks who arrived here in the $13^{\text {th }}$ century (Brennsohn, 1905 , p. 21). In the case of Tallinn, it has been presumed that up to the $1620 \mathrm{~s}$ most of the medical men were clerics (Gustavson, 1969, p. 61).

Although archive materials about medieval medicine in Tartu are few, it can be agreed that the history of medicine in Tartu also began with medieval monastic medicine. There is data about an infirmary and an almshouse at the Holy Spirit Church, which were probably founded in the middle of the $13^{\text {th }}$ century (Otto, 1910, p. 46). A hospital for leprous patients seems to have been founded at the same time (Tartu ajalugu, 1980, p. 52). The first pharmacy in Tartu, was founded between 1422 and 1430 by a learned physician Johann Molner, who arrived from Tallinn and was active in Tartu until 1440 (Brennsohn, 1905, p. 295; 1922, pp. 278-279).

Up to the beginning of the $17^{\text {th }}$ century, the owners of the pharmacy were the only representatives of academic medicine in Tartu. Also, travelling physicians sometimes visited Tartu and treated patients, but most of the healing work was done by local surgeons and barbers (Tartu ajalugu, 1980, p. 94), who did not belong to the ranks of physicians.

Academic medical education in Tartu had its beginnings in the academic gymnasium founded in 1630 and the university founded in 1632. Both institutions were founded in Livonia during the Swedish rule, which tried to consolidate Lutheranism and favoured education. Thus the Swedish King Gustavus Adolphus is considered to be the founder of the University of Tartu. The University of Tartu lay at the periphery of northeastern Europe, and the times were tumultuous (Schmidt-Biggemann, 2010, p. 281). The University of Tartu was called Academia Gustaviana during its first period of activity between 1632 and 1656. One of the three higher faculties at Academia Gustaviana was the Faculty of Medicine, as the model of the University of Paris demanded that all "proper" universities should have a medical faculty (Kallinen, 1995, p. 63). 
Being the easternmost university in Europe at that time, the University of Tartu can be considered the eastern outpost of European medicine in the $17^{\text {th }}$ century as well.

\section{Tuition of medicine at Academia Gustaviana}

As for the tuition in the Faculty of Medicine at the Swedish University of Tartu, the university did not have an anatomical theatre, a botanical garden or a clinic at that time. According to the constitution of the university, the teaching of medicine was based on ancient authors and their commentaries (Constitutiones, 1997, pp. 56-57). Study of chemistry was not included in the curriculum of the medical faculty, although it was widely discussed in Europe at that time.

From the constitution we can see that the medical faculty was planned to have two professorships (Constitutiones, 1997, pp. 56-57), but in reality only one professor of medicine was employed. Sometimes the position of the professor of medicine even remained vacant.

Although the first constitution of the University of Tartu declared that there had to be one dissection of a human cadaver per year (Constitutiones, 1997, pp. 56-57), it can be claimed that these dissections never took place during the first period of activity of the University of Tartu, i.e. between 1632 and 1656. Up to the $19^{\text {th }}$ century it was allowed to dissect only corpses of criminals or the extremely poor (Kallinen, 1995, p. 234). These possibilities probably were not available in Tartu in the first half of the $17^{\text {th }}$ century. It was during the second period the Swedish university-Academia Gustavo-Carolina (16901710) — when the first autopsies, as well as lectures over surgery, took place at the University of Tartu and the importance of clinical teaching was stressed (Tartu Ülikooli ajalugu, 1982, pp. 234-236).

In the $17^{\text {th }}$ century, medical faculties of universities in Europe taught anatomy, surgery, botany, as well as physiology, pathology, therapy and pharmaceutics (Tering, 2010, p. 281). The first constitution of the University of Tartu reveals that not all of these subjects were represented in Tartu.

There is no information on whether the university possessed any medical literature earlier than 1651 (Tartu Ülikooli ajalugu, 1982, p. 251); thus, only personal libraries of the professors of medicine could be used. 
There were very few students studying at the Faculty of Medicine in Tartu in the $17^{\text {th }}$ century. Only two names can been mentioned from among those who studied medicine at Academia Gustaviana and were later active as physiciansDavid Cunitius and Olaus Oestenius. There were also some students who studied at some other faculty in Tartu and later continued their studies in the field of medicine elsewhere in Europe (Rein, 2011, pp. 34-35). The most famous alumnus of the seventeenth-century University of Tartu was the later Doctor of Medicine Urban Hiärne. He stayed in Tartu only for half a year (Tering, 1984, p. 283) during the period when there was no professor of medicine in Tartu.

As there were very few medical students, medical works at the Swedish University of Tartu were most often presented by students of theology and future clergymen, who probably did not have much contact with medicine in their future profession-this discipline was just an extra field of interest for them.

\section{Professors of medicine in Tartu during the first half of the $17^{\text {th }}$ century}

The activities in the field of medicine in Tartu from 1630 to 1656 were influenced by three professors of medicine-Johannes Raicus (ca 1580-1632), Johann Below (1601-1668) and Sebastian Wirdig (1613 or 1615-1687). They all had studied in Germany. In Tartu they became part of the emerging circle of local intellectuals. In addition, learned men with a doctoral degree were allured to Tartu with advantageous perquisites and they acquired a high social position in Livonia as the greatest experts in their field (Tering, 1982, p. 590).

Johannes Raicus, the first professor of medicine in Tartu and the former professor of medicine at Uppsala University, was invited to the Gymnasium of Tartu by Governor-General Johann Skytte in 1630. It has been assumed that the latter was interested in the philosophy of Paracelsus and mysticism of nature (Tartu Ülikooli ajalugu, 1982, p. 183), although this question needs more research. ${ }^{1}$ The medical scholar Johannes Raicus has been claimed to be the most convincing Paracelsist in the history of medicine of Sweden (Lindroth, 1989, p. 388). After his arrival to Tartu, Raicus was appointed the teacher of natural sciences and Rector of the Gymnasium of Tartu with an annual salary of 800 copper thalers (EAA, n.d.). Only Professor Andreas Virginius, the first theologian of

1 Johann Skytte (1577-1645) is generally considered as Ramist (Schmidt-Biggemann, 2010, p. 282). 
the gymnasium, earned more at that educational institution (Piirimäe, 2009, p. 163). Johannes Raicus was to occupy the post of the professor of medicine at the future university as well, but unfortunately he died before the inauguration of the new university, probably in late summer 1632 (Lindroth, 1943, p. 329). The circumstances of his death are still unclear; the last evidence about him being alive is from 13 June 1632, when he wrote a letter to the Chancellor of State Axel Oxenstierna. In this document Johannes Raicus asked for help in solving a problem of immovables, which he had had in Tartu (SRA, 1632). From 1 September his widow received alimony (Schirren, 1854, p. 168) and his funeral took place in October 1632, before the inauguration of the University of Tartu (Recke \& Napiersky, 1861, p. 129).

Johannes Raicus was rector of the Swedish Gymnasium of Tartu and presided the first scientific work connected with the University of Tartu (Raicus \& Turdinus, 1631). He had spent his studies at the Wittenberg University, where he became a licentiate of medicine in 1615. During his earlier career in Germany, Prussia and Sweden he had written papers about paralysis, plague, gout and consumption (Rein, 2010a, pp. 113-120; 2011, pp. 69-77). In Tartu he probably did not have much possibilities to pursue medical activities as he had other official duties as rector of the gymnasium.

The second professor of medicine, Johann Below, stayed in Tartu from 1632 to 1642 . In 1628 he had defended his doctor's thesis at Rostock University (Fabricius \& Below, 1628) and this is the only written work which is known by him. As a professor of medicine in Tartu his annual salary was 700 copper thalers (EAA, n.d.). There were no educated doctors in Tartu at that time and thus Below's main occupation became that of town physician. The obligation of the town physician was also to inspect the activity of pharmacies. At the same time, he was medicus ordinarius at the royal court of law (Tering, 1982, p. 590). After his Tartu period he stayed for some time in Riga, but in 1643 travelled to Moscow as he was invited to be a personal doctor of Russian Tsars (Dumschat, 2006, p. 563).

Sebastian Wirdig was professor of medicine at the University of Tartu from 1647 to 1654 with an annual salary of 350 silver thalers (Vasar, 1932, pp. 170, 179). He had defended his doctoral thesis in 1644 at the University of Königsberg. In his case we have some information concerning his lectures of medicine at the University of Tartu, and he has also been the most prolific of the three professors of medicine while presiding medical disputations. Later he became professor of medicine at Rostock University (Recke \& Napiersky, 1831, p. 536). 
A connecting link between the three professors of medicine who stayed in Tartu from 1630 to 1654 was that they all had spent at least part of their studies at Wittenberg University (Rein, 2011, passim). One of the most famous and popular medical scientists in the first half of the $17^{\text {th }}$ century was Daniel Sennert (15721637), who held the position of professor of medicine at Wittenberg University for many years. Daniel Sennert found a compromise between the ancient medical ideas of Galen and the Renaissance ideas of Paracelsus. Daniel Sennert was the teacher of Johannes Raicus and Sebastian Wirdig (Rein, 2011, p. 138), and his influence can be noticed also in their works. Johannes Raicus himself had disputed under the presidency of Daniel Sennert in Wittenberg (Sennert \& Raicus, 1608); the doctoral thesis of Sebastian Wirdig includes several quotations from Daniel Sennert (Wirdig, 1644), and so do the disputations presided by Sebastian Wirdig in Tartu (Wirdig \& Andreas Arvidi, 1648; and Wirdig \& Oestenius, 1651). One can presume that Johann Below attended the lectures of Daniel Sennert at Wittenberg University as well (Tering, 1997, p. 387).

Only the first professor of medicine in Tartu-Johannes Raicus-was an outstanding scholar before his arrival in Tartu. Neither Johann Below nor Sebastian Wirdig, the next two professors of medicine at Academia Gustaviana, were renowned scholars when they came to Tartu, and for them their careers in Tartu were just springboards to acquire better positions elsewhere in Europe or in Russia.

\section{Tuition of medicine in the $17^{\text {th }}$ century at other Swedish universities}

On the example of the University of Tartu, it can be said that in the first half of the $17^{\text {th }}$ century, tuition of medicine was insufficient. Next we should compare the medical faculty of Academia Gustaviana with other seventeenth-century universities in the Kingdom of Sweden in order to say whether the situation in Tartu was typical or extraordinary.

The first university in the Kingdom of Sweden was Uppsala University, founded in 1477. Subsequent universities were founded in Tartu (1632), Turku (1640) and Lund (1666).

Uppsala University, as the first one, was an example for the University of Tartu in all fields, including in medicine. Medicine was taught at Uppsala only from the 
beginning of the $17^{\text {th }}$ century (Lindroth, 1989, p. 387). The University of Turku together with its medical faculty was founded only eight years after the founding of the University of Tartu. In addition to the same time of foundation, these three universities are also connected through the same professors of medicine and their disciples-Johannes Raicus was professor of medicine both in Uppsala and in Tartu. The first professor of medicine at the University of Turku, Ericus Achrelius (1604-1670), was a student of Johannes Raicus at Uppsala University (Rein, 2011, p. 57).

Johannes Raicus was the third professor of medicine at Uppsala University. The previous professor had complained because of the incomplete tuition of medicine at that university (SBL, 1964-1966, pp. 412-413). Professor Ericus Achrelius at the University of Turku was several times reproached by the university's senate for neglecting his duties, while the former himself complained about the lack of students (Kallinen, 1995, p. 233). Thus it can be concluded that the situation in Uppsala and Turku was similar to that at the University of Tartu in the $17^{\text {th }}$ century-students of medicine were few and tuition in the field of medicine incomplete. No doctoral theses were defended at these universities in the field of medicine during the first half of the $17^{\text {th }}$ century. Students of medicine preferred to complete their studies either in Germany or Netherlands at that time (Tering, 2010, pp. 294-298).

Thus, in Uppsala, things began to change in the second half of the $17^{\text {th }}$ century. One of the most famous scholars in the $17^{\text {th }}$ century was Olof Rudbeck (1630 1702), who discovered the lymphatic system (Lindroth, 1972, p. 108). Modern medical ideas were quickly adopted at Uppsala University, but scholars at Turku preferred to cling to old dogmas (Kallinen, 1995, p. 232). In the following, the medical works at Academia Gustaviana in Tartu are examined in order to shed light on the tendencies in Tartu. 


\section{Works on medicine at the University of Tartu between 1630 and 1656}

One of the sources for medical thought and practice in the $17^{\text {th }}$ century are the medical works of the time. The main competing directions at that time were ancient humoral pathology and iatrochemistry, introduced by Paracelsus and his disciples.

There seems to be a tendency that the first medical works at early modern universities treat medicine as a discipline in general: they define medicine, explain its divisions and inventors, also explain schools of medicine. Medical works from the Kingdom of Sweden in the $17^{\text {th }}$ century fit this pattern as well-the first medical disputations from the universities of Uppsala and Turku deal with medicine in general, i.e. philosophise over the definition, divisions, invention and functions of medicine (Rein, 2011, pp. 57-58).

In Tartu, the tradition of writing medical works began differently. The first medical disputation was defended in 1631, i.e. before the inauguration of the University of Tartu. It was presided by Johannes Raicus and presented by Petrus Turdinus (1609-1653), a future student of theology at the University of Tartu. The title of the disputation was Disputatio physico-medica votiva cis í $\rho \omega \mu \alpha$ surgenti jam Dorpati novo collegio regio ("Physical-medical votive disputation in dedication to the new royal college of Tartu"). It is plausible that the disputation, which presented an overview of the natural conditions of Tartu, gave also evidence of the high level of research at the gymnasium. Thus it is possible that it played some role in accelerating the transformation of the gymnasium into a university.

Johannes Raicus in his disputation gives a survey about chemical constitution of soil and water in the environs of Tartu, about the local endemic diseases and their treatment. He draws his conclusions about Tartu mainly from Hippocrates's work "On Airs, Waters and Places", which also seems to have been the favourite source in his previous writings. Raicus writes about endemic diseases in the region of Tartu and their treatment (Raicus \& Turdinus, 1631).

Proceeding from the theory of Hippocrates which concerns the body humours, Raicus claims that soil and water in the environs of Tartu are bilious. Bile accumulates in the region of Tartu in human bodies, in internal organs. Bile is characterised as a hot humour, analogous to fire, therefore Raicus concludes that the endemic diseases of Tartu and its environments should be acute fevers, 
catarrhs, colic, especially those of stomach, biliary calculus, cholera, obstruction of internal organs and veins, jaundice, scurvy, muscular pain, scabies, abscess, ulcer, Greek leprosy and other similar diseases (Raicus \& Turdinus, 1631).

Raicus raises the question whether the drinking of spirits, which is common in local medical treatment, especially in preventing colic and scurvy, is justified. He describes three different ways for preparing spirits, but finds acceptable only one kind of distillation, which proceeds with the slow fire (Raicus \& Turdinus, 1631).

Raicus promises to continue the discussion raised in the disputation in future, for instance, to expand the theme about the influence of climate on air and therefore on health as well (Raicus \& Turdinus, 1631).

Paracelsus' chemical healing is discussed in the second part of the disputation where Raicus deals with mineral waters and springs. Raicus points out the minerals from which mineral waters are secreted into the ground. The second part of the disputation partly deals with the medical treatment of the diseases which are mentioned in the first part of the disputation (Raicus \& Turdinus, 1631). There is no information regarding whether he actually carried out any research in Tartu; he drew conclusions from the works of authors he had read previously and the main quoted author was Martin Ruland, a disciple of Paracelsus.

At the end of the $17^{\text {th }}$ century, Urban Hiärne dealt with the question of mineral springs in Sweden and provoked interest in them, thus Raicus can be called his predecessor. Johannes Raicus can also be called a pioneer of balneology in the Baltic Sea region.

Professor of medicine Johann Below, who took Raicus's post after his death, communicated with people who were interested in mysticism of nature. It has been presumed that he was interested in Paracelsus's doctrine (Rein, 2010b, p. 64). As no works by Johann Below have been preserved, except for his doctoral thesis which reveals humoral pathological approach to medicine, it is difficult to say anything about his views on medicine (Rein, 2010c, p. 310). Although David Cunitius, the first student of medicine, arrived in Tartu during Johann Below's professorship (Tering, 1984, p. 175), he did not present any medical work at Academia Gustaviana. There are but two orations or academic speeches from that period (1632-1642) dealing with medical themes-Oratio de medicina ("Speech on medicine") from 1637 and Oratio de homine ("Speech on the human being") from 1640. Both were presented by students of theology, the former by Fridericus Heinius and the latter by Segvardus Wallander. 
These two orations are influenced by a scholastic approach to their subject matter-ancient authors and the Bible are important sources for both of them. Early modern medical scientists are mentioned in these academic speeches as well, but their views or writings are not treated at length (Hein, 1637; Wallander, 1640).

The academic speech De medicina praises the healthy living conditions and the mild climate of Tartu, which stimulates vigorous growth of medicinal plants. The oration also demonstrates that dissections of animals (but certainly not of human cadavers) really took place at Academia Gustaviana (Hein, 1637).

The most outstanding doctor according to the author of the oration is God. Heinius emphasises that Jesus often healed people with a single word and mentions characters from the Old Testament, who were healed with the help of God (Hein, 1637).

The speech defined medicine by means of the Latin word 'medium': medicine is as if a midway between the missing and the excessive (Hein, 1637). In the $17^{\text {th }}$ century, medicine and physicians were not considered all-powerful—curing diseases was generally considered just one task of medical science, the other one being medicine's prophylactic function.

From the social aspect, Heinius described diseases which had previously travelled from place to place and emptied whole regions from people. Of deadly diseases he named fever, leprosy and plague, and of serious diseases-hydropsy and phthisis (Hein, 1637).

The oration De medicina does not give us much information about medical conditions in Tartu, neither does Wallander's speech De homine, which describes a man from the theological and the medical point of view. The word homo in Latin is told to be derived from the word humus, which explains the duality of human nature, as he consists of body and soul (Wallander, 1640). The lengthy and thorough anatomical descriptions in the academic speech also reveal that lectures on anatomy, in fact, were delivered at the University of Tartu during the first years of its existence.

These academic speeches can be considered a symbiosis of medical and theological approach to the subject matter. One can also notice that in the medical works of Academia Gustaviana the doctrine of Paracelsus is treated with respect, however, it seems that the students were not very familiar with his ideas. 
Under the presidency of Professor Sebastian Wirdig, the first medical disputations of Academia Gustaviana, entitled Disputatio medica de natura et constitutione medicinae ("Medical disputation on the nature and structure of medicine"; 1648) and Disputatio medica de dysenteria ("Medical disputation on dysentery"; 1651), were defended. The title pages of the disputations name two Swedes-Andreas Arvidi and Olaus Oestenius - as the authors.

Andreas Arvidi, who presented the disputation De natura et constitutione medicinae, became later famous in Sweden as the author of a handbook of poetics. He spent most of his studies in Tartu (1642-1648) during the time when there was no professor of medicine at Academia Gustaviana. Had that not been the case, he quite possibly would have dealt with medicine more profoundly, as his other works written in Tartu reflect his interest in this discipline (Rein, 2011, p. 131).

The disputation De natura et constitutione medicinae may be considered a typical work on medicine from that time, defining medicine through etymology, homonymy and synonymy of the word and also medicine as a phenomenon. The author discusses the causes and aims of medicine, using arguments from Aristotle. The god Apollo is claimed to be the first doctor according to Ovid. There are also questions about the relations of medicine and philosophy (Wirdig \& Andreas Arvidi, 1648).

While De natura et constitutione medicinae has a logical framework and is well argued, it is also quite poetical, talking about ancient gods as inventors of medicine. The disputation of Andreas Arvidi demonstrates that it is possible to philosophise over medicine on 28 pages without mentioning any diseases. There are no local conditions reflected in the work. Andreas Arvidi quotes ancient authors, but at the same time he seems to be well familiar with modern medical authors, such as Daniel Sennert, Jean Fernel and Thomas Bartholin. We can presume that such literature originated from Professor Sebastian Wirdig's personal library, as the same authors are quoted in the latter's doctoral thesis (Wirdig, 1644). Andreas Arvidi stresses the importance of dietetics in his work and in antiquity this branch of medicine was considered to be supreme over pharmacy and surgery (Enzyklopädie Medizingeschichte, 2007, p. 299).

The second disputation (De dysenteria), by a medical student Olaus Oestenius, was defended under the presidency of Professor Sebastian Wirdig. This work is similar to the first disputation in that it contains quotations from Ovid and Daniel Sennert. One can presume that the student used the books which had arrived to the library of the university in 1651 (Rein, 2011, p. 134). The author 
explains the term 'dysentery' -its definition, distinction, reasons, symptoms and treatment. He speaks about air, food, drink, surgery, pharmacy and the necessity of avoiding physical exertion in the case of this disease. He also writes about mitigation of pain for people suffering from dysentery. Some specific remedies against dysentery that Oestenius mentions are mistletoe grown on oak trees, sealed earth, Armenian clay, fresh theriac, and even calcinated human bones. These remedies were said to have been recommended by Daniel Sennert and other contemporary physicians of the time. The disputation is based mainly on humoral pathology. The author claims that dysentery occurs mainly in the autumn and it is often caused by fruits of this season, which can easily become filled with bile. Also, psychological reasons were believed to increase the amount of bile in one's body. Harmful body liquids were recommended to be removed by moderate bloodletting (Wirdig \& Oestenius, 1651).

Thus, while neither the style nor the contents of the two medical disputations presented at Academia Gustaviana under the presidency of Sebastian Wirdig are similar, the quoted sources are the same, which may have been the influence of Sebastian Wirdig. Unfortunately, neither of these two works informs us about the medical conditions in Tartu.

From the five medical works written and presented in Tartu between 1630 and 1656 only the disputation of Johannes Raicus and the oration by Fridericus Heinius give some information about medical conditions in Tartu at that time. This information, however, is necessarily neither objective nor accurate.

Although, similarly to the universities of Uppsala and Turku, no doctoral dissertations were defended in the field of medicine in the first part of the $17^{\text {th }}$ century at the University of Tartu, three medical disputations and two orations were held from 1630 to 1656 . One can conclude that the medical works written in Tartu in this period reflect early modern scientific ideas on medicine as well as mythological and religious picture of medicine and its possible inventors, based on ancient authors and the Bible. 


\section{Conclusions}

When the learned physicians acquired their posts in Tartu in the first half of the $17^{\text {th }}$ century, the new epoch-breaking ideas, such as William Harvey's doctrine about the circulation of blood or Cartesianism, were not being openly discussed yet.

The approach to medical themes in Tartu in the first half of the $17^{\text {th }}$ century was twofold. On the one hand, the situation can be described as rigid following of Greek and Roman authors and the Bible. On the other hand, contemporary medical authorities from the $16^{\text {th }}$ and $17^{\text {th }}$ centuries were becoming increasingly influential.

The founding of the university did not introduce major changes in the field of medicine in Tartu. Academic medicine was not connected with the rest of the medical institutions, such as pharmacy or hospital. Most of the healing work was still done by local surgeons and barbers. Regardless of all, the Swedish University of Tartu can be considered an important centre of early modern medical thought in Eastern Europe, as at that time the University of Tartu was the easternmost university in Europe.

\section{Acknowledgement}

The article has been written with the support of Estonian Science Foundation grant 9098.

\section{References}

Brennsohn, I. (1905), Die Aerzte Livlands von den ältesten Zeiten bis zur Gegenwart: Ein biographisches Lexikon, Mitau: J. F. Steffenhagen.

— (1922), Die Aerzte Estlands vom Beginn der historischen Zeit bis zur Gegenwart: Ein biographisches Lexikon, Riga[: L. Schumacher, Berlin].

Constitutiones (1997), Constitutiones Academiae Dorpatensis (Academia Gustaviana), Tartu Akadeemia (Academia Gustaviana) Póhikiri, Tartu: Tartu Ülikooli Kirjastus.

Dumschat, S. (2006), Ausländische Mediziner im Moskauer Rußland, Stuttgart: Franz Steiner Verlag. 
EAA (n.d.), Hvfwed Book (Liv-und Ingermanland) EAA 278, n 1, s XXII-1, 1 66, Estonian Historical Archives, Tartu.

Enzyklopädie Medizingeschichte (2007), Enzyklopädie Medizingeschichte herausgegeben von Werner E. Gerabek, Bernhard D. Haage, Gundolf Keil, Wolfgang Wegner, Bd. 1, Berlin \& New York: Walter de Gruyter. http://dx.doi.org/10.1515/9783110976946

Fabricius, J. \& Below, J. (1628), De variolis et morbillis theses inaugurales, Rostochi: Acad. Typogr.

Gustavson, H. (1969), Meditsiinist Vanas Tallinnas kuni 1816. aastani, [Medicine in Old Tallinn until 1816] Tallinn: Valgus.

Hein[ius], Fr. (1637), Oratio de medicina: quam in Regia Academia Gustaviana, quae in Dorpati est 31. die Octobris anno 1637. publice enarrabat, Fridericus Heinius, Dorpati Livonorum: Lit. acad.

Kallinen, M. (1995), Change and Stability. Natural Philosophy at the Academy of Turku (1640-1713), Studia Historica 51, Helsinki: Finnish Historical Society.

Lindroth, S. (1943), Paracelsismen i Sverige till 1600-talets mitt, Lychnos-Bibliotek 7 , Uppsala: Almqvist \& Wiksells boktryckeri-A.-B.

(1972), Epoker och människor: Idéhistoriska uppsatser, Stockholm: Wahlström \& Widstrand.

(1989), Svensk lärdomshistoria: Stormaktstiden, Stockholm: Norstedt.

Otto, R. (1910), Ueber die Dorpater Klöster und ihre Kirchen, Dorpat: Druck von C. Mattiesens Buchdruckerei.

Piirimäe, H. (2009), Rootsi riigimajandus Eesti- ja Liivimaal XVII sajandil, [Swedish state economy in Estonia and Livonia in the $17^{\text {th }}$ century] Tartu: EÜS kirjastus.

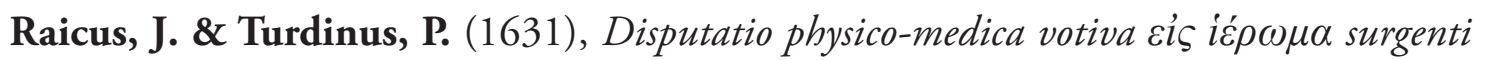
jam Dorpati novo collegio regio, Rigae Livonum: G. Schröder.

Recke, J. Fr. von \& Napiersky, K. E. (1831), Allgemeines Schriftsteller-und GelehrtenLexikon der Provinzen Livland, Esthland und Kurland, Bd. 4, Mitau: J. F. Steffenhagen u. Sohn.

(1861), Allgemeines Schriftsteller-und Gelehrten-Lexikon der Provinzen Livland, Esthland und Kurland. Nachträge und Fortsetzungen unter Mitwirkung von Dr. C. E. Napiersky bearbeitet von Dr. Theodor Beise, Mitau: J. F. Steffenhagen u. Sohn.

Rein, K. (2010a), 'Meditsiinitopograafia Tartu linna kohta aastast 1631,' [The medical topography of Tartu since 1631] Mäetagused, vol. 45, pp. 105-144. http://dx.doi.org/10.7592/MT2010.45.rein

(2010b), "Teoloogiatudengite meditsiiniteemalised oratsioonid Tartu Academia Gustaviana's," [Orations on medicine by theology students at Academia Gustaviana in Tartu] Usuteaduslik Ajakiri, no. 61/2, pp. 53-76.

(2010c), 'Professors of medicine and medical works at Gymnasium Dorpatense and Academia Gustaviana,' Ajalooline Ajakiri. Tartu University and the Early Modern Academic Thought, nos. 3/4 (133/134), pp. 297-321. 
(2011), Arstiteadus rootsiaegses Tartu gümnaasiumis ja ülikoolis aastatel 1630-1656. Meditsiinialased disputatsioonid ja oratsioonid ning nende autorid, [Medicine at the Gymnasium and University of Tartu from 1630 to 1656. Medical disputations, orations and their authors] PhD thesis, Tartu: Tartu Ülikooli Kirjastus.

SBL (1964-1966), Svenskt biografiskt lexikon (1964-1966), vol. 16 (Fich-Gehlin), Stockholm: Riksarkivet.

Schirren, C. (1854), Zur Geschichte der schwedischen Universität in Livland. Mittheilungen aus dem Gebiete der Geschichte Liv-, Ehst- und Kurland's, heraus-gegeben von der Gesellschaft für Geschichte und Altertumskunde der russischen Ostsee-Provinzen. Bd. VII, Heft 1(Riga), Stockholm: Kungl. Boktryckeriet P. A. Norstedt \& Söner.

Schmidt-Biggemann, W. (2010), 'Dynamics of Knowledge in the Seventeenth-Century Swedish Realm,' Ajalooline Ajakiri. Tartu University and the Early Modern Academic Thought, nos. 3/4 (133/134), pp. 281-296.

Sennert, D. \& Raicus, J. (1608), Quaestiones medicae Controversae Quinque, pro Disputatione Nona Propositae, Witebergae: Typis Martini Henckelij.

SRA (1632), Johannes Raicus' letter to Axel Oxenstierna from 13 June 1632, Oxenstiernska samlingen, E 692, National Archives of Sweden, Marieberg.

Tartu ajalugu (1980), [History of Tartu], Tallinn: Kirjastus Eesti Raamat.

Tering, A. (1982), 'Tartu Ülikooli osa Eesti- ja Liivimaa haritlaskonna kujunemises XVII sajandil ja XVIII sajandi algul,' [The role of the University of Tartu in the emergence of Estonian and Livonian literati in the $17^{\text {th }}$ century and the early $18^{\text {th }}$ century] Keel ja Kirjandus, no. 11, pp. 588-596.

— (1984), Album Academicum der Universität Dorpat (Tartu) 1632-1710, Publicationes Bibliothecae Universitatis Litterarum Tartuensis, V. Tallinn: Valgus.

— (1997), 'Höhere Bildung der akademischen Lehrkräfte in den baltischen Provinzen Schwedens,' Europa in der Frühen Neuzeit: Festschrift für Günter Mühlpfordt, Bd. 3, Aufbruch zur Moderne. Herausgegeben von Erich Donnert, Köln \& Wien: Böhlau Verlag Weimar, pp. 383-410.

- (2010), 'Baltimaade ópetatud arste koolitanud ülikoolid 17. sajandil ja 18. sajandi algul,' [Universities training the learned doctors of the Baltic countries in the $17^{\text {th }}$ and $18^{\text {th }}$ century] Läänemere provintside arenguperspektivid Rootsi suurrigis 16/17. sajandil III. Eesti Ajalooarhivi toimetised. Acta et Commentationes Archivi Historici Estoniae, no. 17(24), pp. 280-314.

Tartu Ülikooli ajalugu (1982), [History of the University of Tartu], 1632-1798, vol. 1, Tallinn: Valgus.

Vasar, J. (1932), Tartu ülikooli ajaloo allikaid, I. Academia Gustaviana. a) Ürikuid ja dokumente, [Sources of the History of University of Tartu, I. Academia Gustaviana, a) Manuscripts and documents], Tartu: [Tartu Ülikool].

Wallander, S. O. (1640), Oratio de homine; quam, in Regia Academia Gustaviana, quae 
Dorpati est 28. Mart anno 1640. publice enarrabat Seguardus Olai Wallander, Dorpati Livonorum: Lit. Acad.

Wirdig, S. (1644), Disputatio de palpitatione cordis cum Positionibus 40 inter Medicos frequenter controversis sub finem annexis, Regiomonti: Typis Johannis Reusneri.

Wirdig, S. \& Andreas Arvidi (1648), Disputatio medica de natura et constitutione medicinae; quam, in Academia Gustaviana Adolphina, quae Dorpati est ad diem 2. Septembris anno 1648. sub praesidio Sebastiani Wirdig, publice ventilandam exhibet Andreas Arvidi Stregnensis, Dorpati Livonorum: J. Vogelius.

Wirdig, S. \& Oestenius, O. (1651), Disputatio medica de dysenteria; quam, in Academia Gustaviana Adolphina, quae Dorpati est praeside Sebastiano Wirdig, publicae disquisitioni sistit Olaus N. Oestenius, ad diem [21. 9] anno 1651, Dorpati Livonorum: J. Vogelius.

Kaarina Rein earned her BA and MA degrees in classical philology from the University of Tartu and her PhD degree in religious anthropology from the same university. At the present time she is a lecturer of Latin at the University of Tartu. Her scientific research has been concerned with the Early Modern medical works at the University of Tartu and universities in Scandinavia and with the reception of Modern Greek language and culture in Estonia. Kaarina Rein has translated several texts from Ancient and Modern Greek and Latin into Estonian. 